DOI 10.18551/rjoas.2021-09.11

\title{
ANALYSIS OF LIVELIHOOD DIVERSIFICATION AMONG RURAL FARMING HOUSEHOLDS IN VANDEIKYA LOCAL GOVERNMENT AREA OF BENUE STATE, NIGERIA
}

\author{
Vihi S.K.*, Jesse B., Dalla A.A., Owa G.T. \\ Department of Agricultural Extension and Management, Federal College of Forestry of Jos, \\ Plateau State, Nigeria
}

Bassey E.A., Ochelle B.

Montane Forest Research Station of Jos, Plateau State, Nigeria

Fatoke V.

Department of Agricultural Technology, Federal College of Forestry of Jos, Plateau State, Nigeria

*E-mail: vihisam@gmail.com

\begin{abstract}
The study analyzed livelihood diversification among rural farming households in Vandeikya local government area of Benue State, Nigeria. The specific objectives were to; describe the socio-economic characteristics of farming household in the study area; describe the non-farm livelihoods activities engaged by the farming households in the study area, determine the extent of diversification of farming households, determine the factors influencing livelihood diversification by farming households and identify the constraints to livelihood diversification amongst farming household in the study area. A multi-stage sampling technique was used to select a total number of 192 respondents for the study. Data for the study was garnered using a structured questionnaire designed in line with the objectives of the study. Analysis of the data was done using descriptive statistics such as frequency distributions, percentages and mean as well as Logit regression. Findings revealed the mean age of the farmers to be 40 years with the males constituting the greater percentage $(84 \%)$ of the respondents. The result also revealed that $76 \%$ of the respondents were married with an average household size of 8 persons and an average farm size of 2.5 hectares. The result further shows that the majority $(62 \%)$ of the respondents had only primary education with an average farming experience of 9 years. The majority (93\%) of farmers affirmed that they had no access to credit to finance their production activities. The farmers earned a mean annual farm income of N33518 in the study area. Greater percentage (68\%) of the respondents acquired their farmlands through inheritance. Results also showed that trading, sales of cooked food and local drinks, Casual labour supply and civil service/ private salary jobs were identified as the non-farm livelihood strategies mostly adopted by the households and accounted for $62 \%$, $33 \%, 30 \%$ and $28 \%$ respectively. The level of livelihood diversification in the study area was moderate as the majority of the respondents (74\%) diversified into only two income sources. The result of logit regression shows that the decision to diversify from agriculture to other livelihood means was influenced by age, educational status, membership of cooperatives, access to credit and annual farm income. The leading constraints to livelihood diversification were lack of capital (31\%), lack of non-farm livelihood enterprises $(20.3 \%)$, infrastructural problem (17\%), government policies on use of some natural resources (14.5\%) and gender issues $(11 \%)$. The study recommends the extension of financial institutions to the rural people to enable them have access to credit for agriculture and other income generating enterprises. Appropriate policies and strategies for the development of rural infrastructure based on the current rural livelihood situation should be formed and implemented.
\end{abstract}

\section{KEY WORDS}

Analysis, livelihood, diversification, farming, households. 
A fundamental challenge the world faces today is ensuring that millions of households in poverty have access to enough food to maintain a healthy life. Africa, over the years, has been looking for ways of solving food problem and this has been a topical issue among African leaders, Scholars and all sundry (Sekumade and Osundare, 2014). Nigeria is largely an agrarian country despite its large oil earnings. The agricultural sector is an important sector in the Nigerian economy and other developing countries of the world. It contributes significantly to Gross Domestic Product and employs a large proportion of labour force. Agriculture employs about $70 \%$ of the total labour force, thus making it the most important sector in Nigeria (Chauvin et al., 2012). Nigeria's varied climate which ranges from the tropical areas of the coast to the arid zone of the north affords her the opportunity to cultivate nearly all the types of agricultural produce grown in the tropics and semi-tropical parts of the world (Olayemi et al., 2012).

However, agriculture in Nigeria is characterized by small-scale production which is mainly subsistence with the use of simple crude tools and generally traditional farming methods. Farming as a source of income in Nigeria has failed to bring about enough income for farm households (Babatunde, 2013). Nigeria's agriculture at present is characterized by the weak and inefficient production systems, decayed infrastructure, risk, uncertainty and seasonality among others. The sector is characterized by low yields, low levels of inputs and limited areas under cultivation (Izuchukwu, 2011). It involves small scale farmers scattered over a wide expanse of land area, with small holding ranging from 0.5 to 3.0 hectare per farmland. It is characterized by rudimentary farm systems, low capitalization and low yield per hectare. Some of these challenges are caused by natural resources (soil, water and climate), faulty micro-economies, agricultural policies, bad economy, etc. In the past, it has often been assumed that farm output growth would create plentiful non-farm income-earning opportunities in the rural economy via linkage effects. However, this assumption is no longer tenable; for many poor rural households, farming on its own is unable to provide a sufficient means of survival, and the yield gains of new technology display signs of leveling off. Due to these challenges, smallholder farmers in Nigeria are poverty-stricken as these challenges affect individual farmers and put their household welfare in danger or at risk. Consequently, this risk encourages farmers to diversify into other non-farm activities which are expected to supplement their income. Thus, rural households are now constrained to develop strategies to cope with the vulnerability of agriculture production systems through livelihood diversification.

Livelihood diversification is a process by which rural households construct a diverse portfolio of activities and social support capabilities in their struggle for survival and improvement in their standards of living and the means of gaining a living (Gebru et al., 2018). It can be defined as the maintenance and continuous alteration of a highly varied range of activities and occupations to minimize household income variability, reduce the adverse impacts of seasonality, and provide employment or additional income (Loison, 2015). For rural households, livelihood diversification includes both on-farm and off-farm activities which are undertaken to generate income additional to that from the main household agricultural activities. This could be via the production of agricultural and nonagricultural goods and services, the sale of waged labour, or self-employment in small firms and other strategies undertaken to spread risk. In fact, diversification in rural livelihoods is the subject of conceptual and policy-based research because income from farming has come under pressure due to population explosion (Khatun and Roy, 2016). The context of various risks implies that farm households livelihood diversification is primarily a risk management strategy; both risk adaptation in anticipation of shocks and coping after actual shocks. It is viewed as a general compromise made against the high risk to favour low output and low risk, maximize their personal income and to guarantee smooth consumption expenditure (Kassie and Aye, 2017). Farm households engage and pursue diverse non-farm livelihood activities to cope with diverse challenges and risks such as drought (Gebru and Beyene, 2012). Diversification has two aspects, a shift away from agricultural activities and an increasing mix of income activities. These activities are mostly influenced by livelihood options available in the rural community. According to Ayantoye et al., (2017), decisions on 
diversification can be seen as a coping strategy rather than alternative income opportunities. The share of income from non-agricultural sources gives leverage to the dwindling income from agriculture and considerably improves the livelihood of the rural dwellers (ljaiya et al., 2011). The main driving forces of diversification are: to increase income when the resources needed for the main activities are too limited to provide a sufficient means of livelihood, to reduce income risks in the face of missing insurance market, to exploit strategic complementarities and positive interactions between different activities and to earn cash income and financial investment in the face of credit failures (Dilruba and Roy, 2012). Nonfarm activities have the potential to help households reduce poverty by offering them with a form of insurance against the threats of farming and minimizing reliance on natural resources.

Diversification may occur either as a deliberate household strategy or as an involuntary response to a crisis. According to Loison (2015), individuals and households may diversify their assets, incomes, and activities in response to incentives that may be classified as push and pull factors. Push factors are negative factors that may force farm households to seek additional livelihood activities within or outside the farm (Loison, 2015). Push factors tend to dominate in high-risk and low-potential agricultural environments subject to drought, flooding and environmental degradation (Albore, 2018). According to Loison (2015), push factor is Survival-led diversification which occurs when poorer rural households engage in low-return nonfarm activities by necessity to ensure survival, to reduce vulnerability or to avoid falling deeper into poverty. They are pushed towards diversifying their income sources to manage risks or cope with shocks, such as declines or stagnation in agriculture, differentiated labour markets, credit market imperfections, demographic pressures and land constraints. The most common push factors are related to different forms of risk, such as seasonality and climatic uncertainty (Albore, 2018). Others include land constraints driven by population pressure and fragmented land holdings, missing or incomplete factor markets and market access problems due to poor infrastructure and high transaction costs. Pull factors are positive and these may attract farm households to pursue additional livelihood activities to improve their living standards (Loison, 2015). It is Opportunity-led diversification which occurs when wealthier rural households engage in high-return non-farm activities, with accumulation objectives, in order to increase household income by maximizing returns from their asset. They are able to diversify their income activities in more favorable labour markets or take advantage of offfarm opportunities created by technological advances, new market possibilities, proximity to urban centers or improved infrastructure (Albore, 2018). High returns to nonfarm activities may emerge from increased demand for nonfarm goods and services or off-farm opportunities created by growth motors in different rural sectors such as agriculture, mining or tourism. Better-off households are those with high endowments of assets such as land, livestock and buildings.

In Africa, various studies have shown that while most rural households are involved in agricultural activities such as livestock, crop or fish production as their main source of livelihood, they also engage in other income-generating activities to augment their main source of income. The majority of rural producers have historically diversified their productive activities to encompass a range of other productive areas. In other words, very few of them collect all their income from only one source, hold all their wealth in the form of any single asset, or use their resources in just one activity (Barrett et al., 2001). A previous empirical study by Haggblade et al. (2010) reports that rural residents across the developing world earn $35-50 \%$ of their income from non-farm sources. In Ethiopia, empirical studies found that non-farm income accounts for as much as $40-45 \%$ of the average household income (Bezabih et al., 2010). In this regard, it is obvious that the contribution of non-farm income is immense but varies from place to place and people to people due to different contextual factors. In fact, there are contexts where livelihood diversification strategies can have economic scope effect when rural households invest resources across multiple scopes and obtain higher per unit returns (Gebru et al., 2018).

In Vandeikya Local Government Area of Benue state as well, farming households diversify or engage in other income-generating activities as a way of avoiding risk from 
agricultural disasters or failure, some households diversify into other agricultural sectors/farming strategies while others diversify into non-farm activities like tailoring, crafts and skills like knitting, plaiting of hair/barbing, others engage in civil service jobs. Given that the majority of the farmers are smallholders who produce on a subsistence level, and often do not get optimum economic returns on their produce due to reasons ranging from bad road networks, poor storage facilities, lack of good processing techniques, inadequate government policies, to natural disasters like drought, flood, global warming, etc., some farm households diversify into non-farm activities. Information on the extent of diversification and factors influencing the decision of the household to diversify in the study area is not found in the study area. It is against this backdrop that the study seeks to analyze the livelihood diversification pursued by farming households in Vandeikya Local Government Area of Benue state. The specific objectives were to; describe the socio-economic characteristics of farming household in the study area; describe the livelihoods activities engaged in by the farming household in the study area, determine the extent of diversification of farming households, determine the factors influencing farming household to diversify and describe the constraints militating against the farming household to diversify in the study area.

Test of Hypothesis.

$\mathrm{H}_{0}$ : There is no significant relationship between farmers' socio-economic characteristics and livelihood diversification.

\section{MATERIALS AND METHODS OF RESEARCH}

Vandeikya LGA was carved out of Gboko LGC in 1976. It is located between latitude $7^{\circ} 5^{\prime}$ and $7^{\circ} 15^{\prime}$ north of the Equator and Longitude $9^{\circ}$ and $9^{\circ} 6^{\prime}$ east of Greenwich. The projected population of the local government from the 2006 National Population Census stands at 316,600 (National Population Commission, 2006). It has a landmass of 183,939 square metres (0.7 sq miles) with a population of well over 80,288 . Vandeikya is in the South-Eastern part of Benue State and shares boundaries with Obudu and Bekwara in Cross River State to the East, Ushongo to the North and Konshisha LGA to the West. There are twelve administrative council wards namely Mbadede I, Mbadede II, Mbagbam, Mbagbera, Mbajor, Mbakaange, Mbakyaha, Mbatyough, Mbayongo, Ningev, Nyumagbagh, Township andTsambe. The indigenous community is the Tiv people who speak the Tiv language. The Vandeikya people are a hospitable group and are predominantly Christians with a few traditionalists. Vandeikya Local Government area is dominated by undulating terrain with much of the area being below $183 \mathrm{~m} \mathrm{(600} \mathrm{ft)} \mathrm{above} \mathrm{the} \mathrm{sea} \mathrm{level.} \mathrm{Agriculture} \mathrm{is} \mathrm{the} \mathrm{mainstay}$ of the people; with arable land for sheep, goats and cattle rearing. Over $80 \%$ of the population is directly engaged in the peasant farming of virtually all major food crops, with a concentration on yams, rice, sweet potatoes, cassava, sorghum, citrus, spices, pepper, groundnut and bambara nuts (Vandeikya Local Government Information Office). A multistage sampling technique was used to select farm households. The first stage involved the purposive selection of eight (8) out of the twelve districts in Vandeikya Local Government Area of Benue State for the study. This was done based on the observed prevalence of both on and off-farm activities in the districts. The second stage involved a random selection of two (2) communities from each of the selected districts giving a total of sixteen communities for the study. Finally, from the sample frame of registered farmers obtained from the Benue State Agricultural Development Agency (BNARDA), twelve (12) respondents each were drawn from all the sixteen communities bringing the total of sampled respondents to one hundred and ninety-two (192) farmers for the study. The data was obtained from primary sources. The primary data was obtained through a structured questionnaire and household interviews. Data collected were analyzed using both descriptive and inferential statistics.

The factors influencing livelihood diversification were analyzed using Logistic regression. The logistic (logit) probability function is represented as:

$$
\begin{aligned}
& P i=1 / 1+e^{-z}=f\left(Z_{i}\right) \\
& \log (P / 1-P)=f\left(Z_{i}\right)
\end{aligned}
$$


But $Z_{i}=\beta X_{i}$. Therefore, $\log (P / 1-P)=\left(\beta X_{i}+U_{i}\right)$. Where: $y_{i}=$ connotes dependent variables; $\beta=$ estimated parameters; $x_{i}=$ vector of independent variables; $U_{i}=$ error term; $\log (P / 1-P)=1$, if farmers diversify to non-farm income, while $\log (P / 1-P)=0$ if otherwise. Implicitly, the model is stated as:

$$
Y=f\left(X_{1}, X_{2}, \ldots X_{9}, \varepsilon i\right)
$$

Explicitly it was expressed as:

$$
Y=\beta 0+\beta_{1} X_{1}+\beta_{2} X_{2}+\beta_{3} X_{3}+\beta_{4} X_{4}+\beta_{5} X_{5}+\beta_{6} X_{6}+\beta_{7} X_{7}+\beta_{8} X_{8}+\beta_{9} X_{9}+\varepsilon i
$$

Where:

$Y=$ livelihood diversification (1 if diversify; 0 if otherwise);

$\mathrm{X}_{1}=\operatorname{Sex}(1$ if male; 0 if female);

$\mathrm{X}_{2}=$ Age (years);

$\mathrm{X}_{3}=$ Education (years);

$\mathrm{X}_{4}=$ Household size (number of persons);

$\mathrm{X}_{5}=$ Farm size $(\mathrm{ha})$;

$\mathrm{X}_{6}=$ Access to credit ( 1 if yes; 0 if no);

$\mathrm{X}_{7}=$ Annual income of respondents ( $\$$ );

$\mathrm{X}_{8}=$ Marital status ( 1 if married; 0 if otherwise);

$\mathrm{X}_{9}=$ Farming experience (years);

$\varepsilon i=$ Error term.

\section{RESULTS AND DISCUSSION}

Socio-Economic Characteristics of Farmers. Socio-economic characteristics of the farm households are important factors, directly and indirectly, determining the extent of livelihood diversification in the study area. The results of the socio-economic characteristics of the farm households are summarized in tables 1 below.

Age distribution of the respondents revealed that the majority $(42 \%)$ of the sampled household heads aged between 31- 40 years. The mean age of the household heads in the study area was 40 years. This shows that majority of the farm households were in their economically active age and hence can be actively engaged in agricultural production as well as other livelihood activities. This result is in line with the findings of Ayantoye et al. (2017) who in their study on determinants of livelihood diversification among rural households in Kwara State, Nigeria, also found the mean age of the respondents to be 41.15 years. Sex of the respondents revealed that $84 \%$ of the farmers were male while the remaining $16 \%$ were females. This implies that more male-headed households dominated the captured respondents in the study area. Moreover, rural Nigeria is a patriarchy society with the male dominating as household heads. Hence they are saddled with the responsibility to cater to the welfare of the family. This result is similar to Omotayo (2016) who in his study on the economic synergy between rural off-farm income and household poverty in Ekiti State also found more male-headed farm households in the study area. Gender affects diversification options, including the choice of income-generating activities (both farm and non-farm) due to culturally defined roles, social mobility limitations and differential ownership of/access to assets. The majority (76\%) of the respondents were married while the remaining $24 \%$ of them were single. Marital status is an important factor determining the extent of livelihood diversification. A study conducted by Abiodun et al. (2019) on evaluation of choices of livelihood strategy and diversity of rural households in Ondo State, Nigeria also found that majority $(82.5 \%)$ of the respondents were married. Households that are married are more likely to have diversified income portfolios than unmarried farmers. The responsibility that comes with marriage may necessitate the diversification of livelihood. The household size of the respondents revealed that the majority $(57 \%)$ of the respondents had a household size of 6-10 persons with a mean household size of eight (8) persons. Household size could have 
both positive and negative effects on livelihood diversification. For instance, large households may engage in more income-generating activities for sustainable livelihood than smaller households. This assertion agrees with Ahmed (2012) who opined that the large size of the household may enhance labour availability that can be used for different agricultural activities.

Table 1 - Distribution of Respondents Based on their Socio-economic Characteristics ( $n=192)$

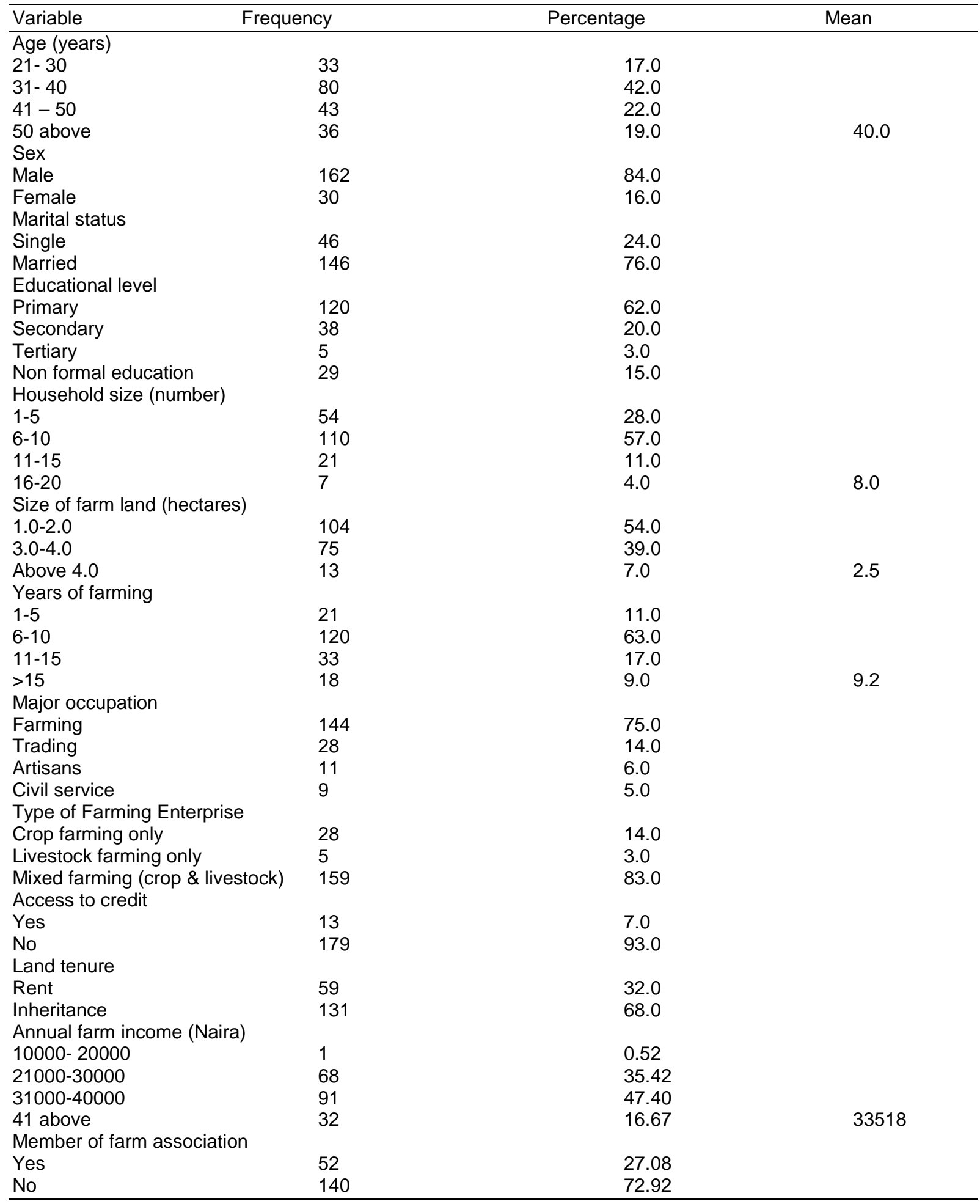

Source: Field survey, 2021. 
The result further revealed that $62 \%$ of the respondents had primary education, about $20 \%$ had secondary education, 3\% had tertiary education while $15 \%$ had no form of education. This result shows that majority of the respondents had at least one form of education. This result agrees with the findings of Abiodun et al. (2019) who also found in their study that majority of the sampled respondent are literates with at least primary school education. Literacy is believed to have a positive implication on efficient use of productive resources, adoption of farm innovation and income diversification. The high level of literacy observed is good for the respondents as they are expected to have a greater knowledge of the importance of diverse income sources. The result also revealed that the majority $(63 \%)$ of the respondents had 6-10 years of experience. The average farming experience of the respondents was 9 years. This result implied that farmers in the study area have sufficient experience in farming. Farming experience of a farmer determines his ability to make effective farm management decisions, not only adhering to agronomic practices but also with respect to input combination or resource allocation. The mean farm size of the respondents was 2.5 hectares indicating that the respondents are predominantly small-scale farmers. Farmers with less land holding would usually respond to livelihood diversification by involving in off/non-farm activities such as selling labor, part-time wage employment, petty trading etc. $75 \%$ of the respondents had farming as their primary occupation while only $25 \%$ had other non-farm economic activities as their primary occupation. This is not strange since the study was directed to farm Households. Majority (83\%) of the interviewed farmers combined crop production with livestock production. Although crop production dominated the farming enterprise in the communities, livestock like poultry, goats, sheep, swine, rabbits etc. were commonly raised around the homestead by almost all the farmers' but usually on a small scale as a source of meet especially during festive periods and also a source of alternative income to augment the earnings from crop farming. The result further indicates that the majority $93 \%$ of farmers had no access to credit to finance their production activities. Adequate funding is required by farmers to finance all crop production and diversified livelihood activities. The result of the annual income of farmers in the study area reveals that farmers earned a mean annual farm income of N33518 in the study area. It can be seen from this result that the annual farm income of farmers in the study area is considered low and majorly for survival rather than totally coming out of poverty. On land tenure, a greater percentage $(68 \%)$ of the respondents said they acquire their farmlands through inheritance while the remaining $32 \%$ acquired their land through rent. The negative effect of the majority using inherited land is that it would lead to fragmentation of farmland as a result of sharing among siblings hence reducing the size of farmland for agricultural practices.

Livelihood Diversification Strategies of the Farming Households. The different livelihood strategies engaged in by the rural households are presented in Table 2 . The result of the various livelihood strategies mostly adopted by the households' shows that trading, sale of cooked food and a local drink, Casual labour supply and civil service/ private salary jobs were identified and accounted for $62 \%, 33 \%, 30 \%$ and $28 \%$. Trading was the most prevalent livelihood strategy among the respondents. This was followed by a sale of cooked food and local drink. Although trade is mostly considered as a dominant livelihood strategy of urban society, it is not solely confined to urban dwellers. Thus, rural households also employed trade as their major as well as a supportive livelihood strategy in the study area. The sale of locally produced drinks and cooked foods was the next livelihood activity engaged by the farmers. The study revealed that in most instances, female-headed households especially widows and divorcees are usually pushed or pulled to such activities when their livelihood situation deteriorates following the death of a spouse or unfair property division when marriages fail. This might be due to difficulties that female-headed households face in keeping the farm economy as their major livelihood activity after they lose their spouse. In the case of casual labour, some members of a given household would work on other farmland so as to generate income or moving to urban areas to serve as a daily labourer on construction sites. Nowadays, investment in non-farm business needs high financial capital and there is no way of getting higher financial capital to invest it in non-farm business activities. Hence, farming households prefer to engage in some non-farm livelihood 
activities that do not require much more financial capital. This finding is in line with Rukwe et al. (2019) who in their study on rural farmers' households livelihoods security options amidst conflicts in Taraba State, also found that off-farm income generating activities in the study area were skewed towards trading, sales of cooked food, foodstuff, casual daily labour, selling local liquor among others because it requires relatively less capital to start-up.. The result therefore indicates that the respondents are majorly agrarian rural dwellers. They depend mostly on the proceeds from their farms to survive and meet their daily food and other necessary requirements. The study also reveals that diversification is yet to be developed as the respondents still depend majorly on agriculture. This confirms the previous finding that Agriculture is the bedrock of sustenance in the Nigerian society.

Table 2 - Distribution of respondents based on the type of non-farm activities adopted

\begin{tabular}{llll}
\hline Secondary occupation & ${ }^{*}$ Frequency & Percentage & Rank \\
\hline Civil service/ private salary jobs & 53 & 28.0 & $4^{\text {th }}$ \\
Trading & 119 & 62.0 & $1^{\text {st }}$ \\
Sale of cooked food and local drink & 63 & 33.0 & $2^{\text {nd }}$ \\
Casual labour supply & 57 & 30.0 & $3^{\text {rd }}$ \\
Mason & 13 & 7.0 & $11^{\text {th }}$ \\
Commercial driver/cyclist & 26 & 13.5 & $7^{\text {th }}$ \\
Tailoring & 27 & 14.0 & $6^{\text {th }}$ \\
Income from rent of assets & 17 & 9.0 & $8^{\text {th }}$ \\
Carpentry & 14 & 7.2 & $10^{\text {th }}$ \\
Barbing/hair dressing & 11 & 6.0 & $12^{\text {th }}$ \\
Brick laying & 29 & 15.1 & $5^{\text {th }}$ \\
Painting & 11 & 6.0 & $12^{\text {th }}$ \\
Shoe making & 6 & 3.1 & $15^{\text {th }}$ \\
Selling firewood & 14 & 7.2 & $10^{\text {th }}$ \\
Vulcanizing & 8 & 4.1 & $13^{\text {th }}$ \\
Mechanic & 7 & 4.0 & $14^{\text {th }}$ \\
Others & 15 & 8.0 & $9^{\text {th }}$ \\
\hline
\end{tabular}

The extent of Livelihood Diversification. This examines the degree of livelihood diversification in the study area. It looks at how many livelihood activities a farming household is engaged in. The table below shows that $7 \%$ of farm households did not diversify into non-farm activities as they depended on a single income source which was farming. 74\% percent were moderately diversified (depend on two income sources) and only $19 \%$ were highly diversified (more than two income sources). It is clear from table 3 that the majority of farming households had a moderate level of diversification. It should be noted that diversification in the context of this study means having other sources of livelihood in addition to the existing farming. Furthermore, the result shows that the majority of farming households do not depend on one source of livelihood. This strategy is adopted to ensure income security and reduce poverty. This security mechanism works on the basis that when the sale or production levels in one enterprise fail, the proprietors are able to switch to the other enterprise. The result is in line with studies conducted by Okere \& Shittu (2013) and Idowu et al. (2014) where the majority of farming households moderately diversify their sources of livelihood.

Table 3 - Distribution of respondents based on Extent of livelihood diversification

\begin{tabular}{lll}
\hline Extent & Frequency & Percentage \\
\hline Not diversified & 13 & 7.0 \\
$1-2$ (Moderately) & 142 & 74.0 \\
$3-4$ (Highly) & 37 & 19.0 \\
Total & 192 & 100 \\
\hline
\end{tabular}

Source: Field survey, 2021.

Reasons for Livelihood Diversification. As presented in Table 4, respondents had various reasons for diversifying into other activities. The most important reason for livelihood 
diversification among farm household heads was to augment poor earnings from agriculture $(72 \%)$ followed by risk and uncertainties in agriculture (13\%). It could be seen from this result that, the main reason for diversification reported by the majority of the respondents in the study area was the desire to augment poor earnings from agriculture.

Table 4 - Distribution of Respondents based on reasons for diversification

\begin{tabular}{lll}
\hline Reason & Frequency & Percentage \\
\hline To augment poor earnings from agriculture & 139 & 72.0 \\
Small farm size & 10 & 5.0 \\
Availability of non-farm opportunities & 6 & 3.0 \\
Seasonal nature of agricultural production & 13 & 7.0 \\
Risk and uncertainties in agriculture & 24 & 13.0 \\
\hline
\end{tabular}

Factors Influencing Farmers Livelihood Diversification. The Logit model was used in estimating factors that influenced livelihood diversification by farmers in the study area. The estimated coefficients of the Logit model, along with the standard error and T-values are presented in Table 5. The log-likelihood function (-76.08) shows that the estimated model including a constant and the set of explanatory variable fit the data better. This implies that all the variables included in the Logit model are jointly significant in influencing farmers' decision to diversify to other income-generating activities. According to the results, five (5) out of eight predicators namely; age, educational status, membership of cooperatives, access to credit and annual farm income were statistically significant. The result shows that the decision to diversify from agriculture to other livelihood means was positively influenced by age and membership of cooperatives both at $5 \%$ and negatively influenced by educational status, access to credit and annual farm income at $5 \%, 5 \%$ and $1 \%$ respectively.

The coefficient of age was found to be significant and positively related to livelihood diversification. This implies that with the advancement in age of household heads, their involvement in non-agricultural activities increases. This is not surprising as accumulated experience contributes to the skills needed to diversify income-generating activities, thereby increasing the per capita income of the household. Experience increases with age and consequently, experienced persons have more prospects of getting jobs in the non-farm sector. Aged household heads have a larger family size and are likely to have extra and unemployed labour to allocate outside the agricultural sector. This finding agrees with Dilruba and Roy (2012); Gecho (2016), Irohibe and Agwu (2014) who in their separate studies found a positive relationship between age and livelihood diversification. However, the finding is in contrast with other authors like Aababbo and Sawore, 2016; Abimbola and Oluwakemi, 2013; Adepoju and Oyewole, 2014 who found a negative relationship between age of the household head and livelihood diversification.

The educational level of the farm household head was significant at $5 \%$ and negatively related to livelihood diversification decisions of farm households. This result depicts that farm households who attended secondary and higher educational level would exhibit lower probability of diversifying into non-farm activities. The possible explanations may be that farm households who attained secondary and higher educational level may concentrate on specializing in on-farm activities by employing better farm technologies towards increasing their food productivity. This result is contrary to earlier empirical findings of Afodu et al. 2019; Fufa, 2015; Adepoju and Oyewole, 2014; Akaakohol and Aye (2014) who in their separate studies found a strong positive relationship between education and livelihood diversification.

The coefficient of membership of cooperatives was significant at $5 \%$ correlating positively with livelihood diversification. Membership in cooperatives increases the probability of participating in livelihood diversification activities. The finding suggests that belonging to farmers organization would significantly influence farmers into livelihood diversification activities besides farming because the experience of working and sharing ideas and common problems in groups would educate the farmers and also enable them to learn more about other opportunities which may exist outside his immediate environment. Farm households' 
social capital and entrepreneur skill will be increased as they become a member of the cooperatives.

The coefficient of annual farm income is significant at $1 \%$ and correlated negatively with livelihood diversification implying that the higher the farm income of the farm households, the lower the level of livelihood diversification. This result is contrary to expectations as farmers who earn a higher monthly income should indulge in other livelihood activities other than farming. But in this study, the coefficient of farm income is negatively significant which contradicts the apriori expectations. However, the plausible explanation for this scenario is that household heads with high farm income would be motivated to concentrate more on farming rather than engage in other off-farm activities. This result collaborates the findings of Adekunle and Shittu (2014) who in their study on patterns and determinants of livelihood diversification among farm households in Odeda Local Government Area, Ogun State, Nigeria also found a significant and negative relationship between farm income and livelihood diversification.

The coefficient of access to credit was found to be significant and negatively related to livelihood diversification. This implies that farmers with access to credit are unlikely to engage in other income-generating activities. This result is contrary to expectations. Ordinarily, access to credit should have a positive and significant effect on livelihood diversification. But in this study, the coefficient of access to credit is negatively significant which contradicts the apriori expectations. This result is in contrast to Afodu et al. (2019). These authors posit that the more household access credit facilities, the more the capital available for off-farm investment.

Table 5 - Logit regression results on Factors influencing livelihood diversification

\begin{tabular}{lllll}
\hline Variable & Coefficient & Std Error & Z & P value \\
\hline Constant & 16.8951 & 6.6256 & 2.55 & 0.011 \\
Age & .095857 & .05625 & 1.70 & $0.088^{\star *}$ \\
Education level & -.1469 & .0652 & -2.25 & $0.024^{* *}$ \\
HHsize & -.00009 & .00006 & -1.34 & 0.179 \\
F/ experience & -.3138 & .2302 & -1.36 & 0.173 \\
Member of orgztn & 1.2086 & .5732 & 2.11 & $0.035^{\star *}$ \\
Contact with ext & .4421 & .4351 & 1.02 & 0.310 \\
Annual farm income & -3.6919 & 1.4152 & -2.61 & $0.009^{\star * *}$ \\
Access to credit & -1.0334 & .4474 & -2.31 & $0.021^{* *}$ \\
No. of observations $=192$ & & & & \\
LR Chi2 (8) = 30.17 & & & & \\
Log likelihood =-76.0870 & & & & \\
Pseudo R ${ }^{2}=0.1654$. & & & & \\
\hline
\end{tabular}

Note: ${ }^{* *}$, Significant at 5\%, ${ }^{* * *}$, Significant at $1 \%$.

Constraints to Livelihood Diversification. The distribution of constraints faced by respondents is shown in Table 6 . The leading constraints faced by the respondents were lack of capital $(31 \%)$, lack of non-farm livelihood enterprises $(25 \%)$, infrastructural problem $(21 \%)$, government policies on the use of some natural resources $(14.5 \%)$ and gender issues $(11 \%)$.

Lack of capital was the major constraint of non-farm livelihood diversification reported by the study population. Lack of capital in this sense does not represent the various forms of capital rather, it is only associated with the financial type of capital. Although some farming households need to invest on non-farm livelihood business options, they face acute entry barriers in terms of financial capital. Hence, farming households prefer to engage in some non-farm livelihood activities that do not require much more financial capital. In this regard, temporary wage labour is often prime choices due to no need for start-up capital rather the labour of an individual.

As shown in the table, the lack of organized non-farm livelihood generating enterprise is the second most important constraint that limits livelihood diversification. According to the view of sampled respondents in the study area, there is no organized nonfarm livelihood 
generating enterprise that can motivate, provide technical and financial assistance to farming households so as to engage in non-farm livelihood activity other than agriculture.

The infrastructural problem which is evident in bad roads, poor electricity among others stops household heads from adopting some form of livelihood as it increases the cause of establishment and operation. For example, bad road networks between communities increase the cost of transportation to the market where large income could be attained in the form of profit.

There are several bans on natural resources such as land, forest, and water bodies due to the cultural values and norms of the study area. These cultural norms and values are likely to prevent the household head from considering livelihood activities related to natural resources.

Some cultural norms also prevent women from accessing several benefits in rural areas. Thus, limits access to some resources gender-wise. These could be the reason for the moderately diversified nature of livelihoods in the study area as these constraints pose a serious threat to the expected outcome of households' livelihood diversification efforts.

Table 6 - Distribution of respondents based on constraints to Livelihood Diversification

\begin{tabular}{lll}
\hline Constraint & ${ }^{*}$ Frequency & Percentage \\
\hline Lack of non-farm livelihood enterprises & 48 & 25.0 \\
Lack of adequate capital & 59 & 31.0 \\
Govt. policies on use of some natural resources & 28 & 14.5 \\
Infrastructural problems & 41 & 21.0 \\
Gender issues & 21 & 11 \\
Others & 12 & 6.2 \\
\hline
\end{tabular}

Test of Hypothesis: Decision. From the result of the logit regression, some socioeconomics demographics of the respondents such as age, educational status, and annual farm income were statistically significant. Therefore we reject the null hypothesis which stated that there is no significant relationship between farmers' socioeconomic characteristics and livelihood diversification.

\section{CONCLUSION AND RECOMMENDATIONS}

The study analyzed livelihood diversification among rural farming households in Vandeikya local government area of Benue State, Nigeria. Results showed that trading, sale of cooked food and local drinks, Casual labour supply and civil service/ private salary jobs were identified as the most important livelihood strategies adopted by the households' in the study area. The level of livelihood diversification in the study area was moderate as the majority of the respondents diversified into only two income sources. The decision to diversify from agriculture to other livelihood means was influenced by age, membership of cooperatives, educational status, access to credit and annual farm income respectively. The constraints to livelihood diversification include; lack of capital, lack of non-farm livelihood enterprises, infrastructural problems, government policies on the use of some natural resources and gender issues. It was recommended that governmental and nongovernmental organizations should give attention to rural livelihood improvement through providing information regarding credit services, marketing and existing non-farm livelihood enterprises. Policymakers should formulate and ratify appropriate rural infrastructural development policies and strategies based on the existing situation of rural livelihood to boost the development of the rural community.

\section{CONFLICT OF INTERESTS}

The authors have declared no conflict of interest. 


\section{REFERENCES}

1. Aababbo, Y., \& Sawore, A. (2016). Assessing Determinant Factors of Income Diversification among Rural Farm Households in Ethiopia: The Case of Leemo and Anileemo Districts, Hadiya Zone, South Nation Nationalities People Region. International Journal of Science and Research (IJSR) 5(12):100-110 DOI: 10.21275/ART20163308.

2. Abimbola, A. O., \& Oluwakemi, O. A. (2013). Livelihood Diversification and Welfare of Rural Households in Ondo State, Nigeria. Journal of Development and Agricultural Economics. Vol. 5(12), pp.482-489.

3. Abiodun,T .C., Adewale, I. O., \& Ojo, S. O. (2019). Evaluation of Choices of Livelihood Strategy and Livelihood Diversity of Rural Households in Ondo State, Nigeria. Journal of Social Sciences and Humanities. Vol. 5, No. 1, 2019, pp. 17-24.

4. Adekunle, C. P., \& Shittu, A. M. (2014). Patterns and Determinants of Livelihood Diversification among Farm Households in Odeda Local Government Area, Ogun State, Nigeria. Journal of Agricultural Science and Environment. 14:27-35.

5. Adepoju, A.O., \& Oyewole, O.O. (2014). Rural Livelihood Diversification and Income Inequality in Akinyele Local Government Area, Ibadan, Oyo State, Nigeria. Journal of Agricultural Sciences, 59(2): 175-186.

6. Afodu, O. J., Afolami, C. A., Akinboye, O. E., Ndubuisi-Ogbonna, L. C., Ayo-Bello, T. A., Shobo, B. A. \& Ogunnowo, D.M. (2019). Livelihood Diversification and it's Determinants on Rice Farming Households in Ogun State, Nigeria. African Journal of Agricultural Research. Vol. 14(35), pp. 2104-2111, December, 2019. DOI: 10.5897/AJAR2019.14205.

7. Ahmed, F. F. (2012) Income Diversification Determinants among Farming Household in Konduga, Borno state, Nigeria. Journal of Academic Research International 2(2) 555-561

8. Akaakohol M. A., \& Aye, G. C. (2014). Diversification and Farm Household Welfare in Makurdi, Benue State, Nigeria. Development Studies Research. An Open Access Journal, 1:1, 168-175, DOI: 10.1080/21665095.2014.919232.

9. Albore, A. (2018). Review on Determinants of Sustainable Rural Livelihood Diversification Of Small Holder Farmers in Ethiopia. Int. J. Adv. Res. 6(2), 251-259International Journal of Advance Research (IJAR).

10. Ayantoye, K.I., Amao, J. O., \& Fanifosi, G. E.(2017). Determinants of Livelihood Diversification among Rural Households in Kwara State, Nigeria. International Journal of Advanced Agricultural Research, 5, 82-88.

11. Babatunde, H.J.(2013). Non-farm Inequality and Land in Rural Egypt. Economic Development and Cultural Change, 50(2), 339-363.

12. Barrett, C.B., Reardon, T., \& Webb,P. (2001). Non-farm Income Diversification and Household Livelihood Strategies in Rural Africa: Concepts, Dynamics, and Policy Implication. Food Policy. 26(4): 315-331.

13. Bezabih, M.(2010). Participation in off-farm employment, rainfall patterns, and rate of time preferences: the case of Ethiopia. 2010.

14. Chauvin, N. D., Mulangu, F., and \& Porto. G. (2012). Food Production and Consumption Trends in Sub-Saharan Africa: Prospects for the Transformation of the Agricultural Sector." UNDP Regional Bureau for Africa, WP 2012-011.

15. Dilruba, K., \& Roy, B.C. (2012). Rural Livelihood Diversification in West Bengal: Determinants and Constraints. Agricultural Economics Research Review, Vol. 25(No.1) January-June 2012 pp 115-124.

16. Fufa, M. (2015). Factors Responsible for Income Diversification among Rural Households in Agafa District, Bale Zone, Oromia National Regional State, Ethiopia. Unpublished M.Sc thesis, Department of Rural Development and Agricultural Extension, School of Graduate Studies, Haramaya University, Haramaya, Ethiopia.

17. Gebru, G W., Hyacinth, E. I., \& Ogbonnia, PE.(2018). Determinants of Livelihood Diversification Strategies in Eastern Tigray Region of Ethiopia. Agriculture \& Food Security. (2018) 7:62 https://doi.org/10.1186/s40066-018-0214-0. 
18. Gebru, GW., \& Beyene, F. (2012). Rural Household Livelihood Strategies in Droughtprone Areas: A Case of Gulomekeda District, Eastern Zone of Tigray National Regional State, Ethiopia. J Dev Agric Econ. 4(6):158-68.

19. Gecho, Y. (2016). Rural Farm Households' Income Diversification: The Case of Wolaita Zone, Southern Ethiopia. International Journal of Sustainable Development Research, 2 (2): 6-17.

20. Haggblade, S., Hazell, B., and\& Reardan, T. (2006) .The Rural Non- Farm Economy: Pathway out of Poverty or pathway in? Transforming The Rural Non-farm Economy. Baltimore, John Hopkins University Press.

21. Idowu, A. O., Ambali, O.I., \& Onasanya, A. S. (2014). Living Condition, Livelihood and Crop Diversification among Rural Farm Households in Remo Division of Ogun State Nigeria. Asian Journal of Agricultural Extension,Economics and Sociology.3(6): 619-629.

22. ljaiya, G. T., ljaiya, M. A., Bello, R. A., \& Ajayi, M. A. (2011). Economic Growth and Poverty Reduction in Nigeria. International Journal of Business and Social Sciences, 2(15), 147-154.

23. Irohibe, I. J., and\& Agwu, A.E. (2014). Assessment of Food Security Situation among Farming Households in Rural Areas of Kano State, Nigeria. Journal of Central European Agriculture, 15(1): 94-107.

24. Izuchukwu, O. (2011). Analysis of the Contribution of Agricultural Sector on the Nigerian Economic Development. World Review of Business Research, 1(1): 191- 200.

25. Kassie, G.W., \& Aye, G. (2017). The Nexus between Livelihood Diversification and Farmland Management Strategies in Rural Ethiopia. Cogent Econ Finance. 5(1):1275087.

26. Khatun, D., \& Roy, B.C. (2016). Rural Livelihood Diversification in West Bengal: Nature and Extent. Agric Econ Res Rev. 29(2):183-90.

27. Loison, S. A. (2015). Rural Livelihood Diversification in Sub-Saharan Africa: A Literature Review. Journal of Development Studies, 51 (9), 1125 -1138.

28. Losch, B., Freguin-Gresh, S., \& White, E. T. (2012).Structural Transformation and Rural Change Revisited: Challenges for late developing countries in a globalizing world. Agence Française de Developpement and the World Bank: Washington, DC: World Bank Publications.

29. National Population Commission (2006). Nigeria Census Statistical Bulletin in Report. Vol. 6, ISBN: 978-35734-8-9.

30. Okere, C.P., \& Shittu, A.M. (2013). Patterns and Determinants of Livelihood Diversification among Farm Households in Odeda Local Government Area, Ogun State, Nigeria. Journal of Economics, 1(1): 1-12.

31. Olayemi, F. F., Adegbola, J.A., Bamishaiye, E.I., and\& Awagu, E.F. (2012). Assessment of Post Harvest Losses of Some Selected Crops in Eight Local Government Areas of Rivers State, Nigeria." Asian Journal of Rural Development 2 (1): 13-23.

32. Omotayo, A.O. (2016). Economic Synergy between Rural Off-farm Income and Households' Poverty in Ekiti State, Nigeria. Journal of Human Ecology, 56(1,2), pp. 99106.

33. Rukwe, D.T., Oladimeji, E.D., \& Tsukutoda, I.I. (2019). Rural Farmers Households Livelihoods Security Options amidst Conflicts in Taraba State, Nigeria South Asian Research Journal of Agriculture and Fisheries. Volume-1 Issue-3. Oct-Nov -2019.

34. Sekumade, A.B., and\& Osundare, F.O.(2014). Determinant and effects of livelihood diversification on farm households in Ekiti State, Nigeria. Journal of Economics and Sustainable Development, 5(5), 1-2.

35. Vandeikya Local Government Information Unit. 